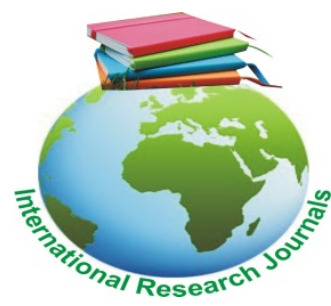

Educational Research (ISSN: 2141-5161) Vol. 7(3) pp. 072-087, May, 2016

Available online@ http://www.interesjournals.org/ER

DOI: http:/dx.doi.org/10.14303/er.2016.138

Copyright (C) 2016 International Research Journals

Full Length Research Paper

\title{
Student Factors Influencing Academic Performance of Students in Secondary Education in Kenya: A Case Study of Kakamega County
}

\author{
Elizabeth Luttah Waseka and *Enose M.W. Simatwa
}

\begin{abstract}
Department of Educational Management and Foundations, Maseno University Department of Educational Management and Foundations, Maseno University

*Corresponding Author's Email: simatwae@gmail.com
\end{abstract}

\begin{abstract}
Quality of education is assessed on the basis of learners' achievement. Performance in Kenya Certificate of Secondary Education examinations is therefore a good indicator of the quality of education offered in schools. This is because it is a standardized instrument and therefore a reliable measure. In the years 2011 to 2014 Kakamega County posted mean scores of 5.439, 5.228, 5.363 and 5.654 respectively. These means translate to an average of $C$ - for the years 2011-2014 which was below the acceptable minimum quality grade of $C+$ that enables candidates pursue competitive courses such as medicine, pharmacy, engineering, architecture, law, teaching among others in tertiary institutions and at university level. The key factors based on studies that have been conducted on factors that influence students' academic performance in secondary education are: principals, teachers, students, school factors and government policies. The number one factor is the student. This is because she is the person who stands to lose or gain ostensibly from performance in Kenya Certificate of Secondary Education examinations. Students are products of Kenya Certificate of Secondary Education examinations process. It is against this backdrop that this study investigated student factors' influence on student academic performance in secondary education in Kenya using Kakamega County as the site for the study. The study population consisted of 324 secondary school principals, 324 Deputy principals, 1 County Education Quality Assurance and Standards Officer and 9,000 Form IV students of 2014 cohort. Regression analysis technique was used to establish the influence of student factors on students' academic performance. This study established that student factors influenced student academic performance by $\mathbf{7 . 5 6 \%}$. The other $24.4 \%$ was due to other factors which were not subject of this study. Performance in Kenya Certificate of Primary Education, age, participation in co-curricular activities and exclusion from school were student factors that were statistically significant predictors of students academic performance in Kenya Certificate of Secondary Education examinations whereas Kenya Certificate of Primary Education mark, exclusion from school and co-curricular activities enhanced students academic performance, age (18 years and above) reduced students academic performance. Unrest absenteeism from school, class and preps were not statistically significant predictors of students' academic performance.
\end{abstract}

Keywords: Student Factors, Academic Performance, Students, Secondary Education, Kakamega County, Kenya.

\section{INTRODUCTION}

Student factors, teacher factors and government policies are vital in achieving quality secondary education. The achievement of universal participation in education fundamentally depend on these factors. For example, 
how well pupils are taught and how much they learn, can have a crucial impact on how long they stay in school and how regularly they attend. It could be judged unfortunate therefore that the quantitative aspects of education have become the main focus of attention in recent years for policy makers (Education for All, 2005). The achievement of quality education requires the collective effort of various stakeholders. Effort needs to be made by students, teachers, school principals and the government in order to realize desirable quality standards in secondary education. The schools also require specific facilities and optimum conditions in order to facilitate the efforts of the teachers, students and principals. This study examined the role played by each of these factors in providing quality secondary education. The goal of achieving Universal Primary Education has been on the international agenda since the Universal Declaration of Human Rights affirmed in 1948 that elementary education was to be made freely and compulsorily available for all children in all nations. This objective was restated subsequently on many occasions, by international treaties and in United Nations conference declarations. Most of the declarations and commitments however are silent about the quality of education to be provided (Education for All, 2005).

According to Oniye and Alawaye (2008), the importance of examination or test taking for diagnostic placement, classification and quality control in Nigeria institutions have been greatly eroded and corrupted with increasing incidence of examination malpractice. They further assert that examination malpractice constituted one of the most debilitating problems facing the Nigerian education institutions and were constantly manifested and reported in their schools, colleges and other higher institutions. It is therefore important to prioritize and set quality teaching as a strategic objective for institutions to signal the institutions' commitment to fostering continuous improvement in teaching and learning (Henard and Roseveare, 2012).

The Basic Education Act (2013) provides for the right of every child to free basic education. It further provides for the right of every child in a public school to equal standards of education. This study therefore recognized the importance of the students in accessing education and also attaining quality standards comparable to their peers in other sub county and counties.

Newsberger (2003) established that 20 percent of high school students were in some kind of alienation from the educational system at any given time. This alienation created the kind of environment that easily prompted students to cheat to get admissions or scholarships to the next level. This study established the various reasons that contributed to students cheating in examinations. In a different study done in Nigeria, Udoh (2011) established that parents not wishing their children to repeat any class colluded with principals to issue fake but favourable results to their children. Watitwa (2010) on the other hand concluded that there is a statistically significant relationship between students' motivation and achievement in Biology practical work. What was known from these studies was that parents would not hesitate to aid their students in examinations and that students' motivation was likely to boost high scores in Biology practicals. This implies that a teacher is expected to make every effort to expand knowledge of his own subject and to improve his teaching technique. He/she is also expected to impart relevant knowledge, skills, attitudes and values to the learner. According to this study therefore the teacher was a major contributing factor to students' academic performance in secondary education in a school and by extension in the county. A study on factors affecting students' experiences and satisfaction about teaching quality in engineering by Calvo, Markauskaite and Trigwell (2000) established that supportive teachers and their ability to explain clearly were the most influential factors that impacted students' satisfaction. On the other hand Chevedza, Wadesango and Kurebwa (2012) researched on factors that militate against the provision of quality education in Zimbabwe. They concluded that hiring of expatriate personnel in education was a noble development to help fill the deficit created by skilled teachers who have migrated to other countries. In a different study done by Sichambo (2011) in Bungoma North District it emerged that secondary school teachers, apart from the classroom teaching had other responsibilities which were causing moderate burnout and thus performance had moderately slowed down. The above studies established that teachers were the most influential factor that impacted students' satisfaction and that hiring of expatriate teachers helped alleviate the staffing problem and that overload of responsibilities impacted negatively on teachers' performance. A teacher is expected to make every effort to expand knowledge of his own subject and to improve his teaching technique (Ministry of Education Science and Technology, 1987). He/she is also expected to impart relevant knowledge, skills, attitudes and values to the learner (The Basic Education Act, 2013).

\section{Research Objective}

To establish the influence of student factors on students' academic performance in secondary education in Kakamega County

\section{Synthesis of literature on Student factors that influence Students' Academic Performance in Secondary Education}

Learning is measured from what learners are able to do 
as a result of learning. When learners show relative change in behavior as a result of learning the new behavior should be positive and beneficial to society. The knowledge, skills and attitudes learned by students are often measured in oral and written achievements (Otunga, Odero and Barasa, 2011). The quality of students' performance therefore remains a top priority for educators. It is meant for making a difference locally, regionally, nationally and globally. Educators, trainers and researchers have long been interested in exploring variables contributing effectively to quality of performance of learners. These variables that affect students' quality of academic achievement are inside and outside of school (Farooq, Chaudry, Shafiq and Berhamu, 2011). The study by Farooq et al (2011) examined the different factors influencing the academic performance of secondary school students. The present study specifically examined the influence of study habits, peer influence, absenteeism, indiscipline and students' entry behavior (Kenya Certificate of Primary Education) on students' academic performance in secondary education.

Students prepare-if at all they do-lackadaisically for examinations. The reason for this according to myspacefm (2004) was because the youth have prioritized entertainment and pleasure at the expense of their books. Udoh (2011) on the other hand established that poor study habits are significant remote causes of examination malpractice in Nigeria and that by exposing the influence of poor study habits students and education stakeholders could tame the rising tide of examination crime. The zeal of students to study can be ignited by exposing them to continuous assessment procedure which would also enable them develop self-confidence and put less emphasis on certification (Onyechere, 1996).In a study done in America, Newsberger (2003) found out that about 20percent of high school students were in some kind of alienation from the education system at any given time. They were working too many hours in paid employment to cope with schoolwork or they had been devastated by drugs or alcohol or crime, or they were distracted by psychiatric or severe family problems among the more common reasons. What this meant was that almost everyone except the alienated student was pushing toward the door to college. In that kind of environment, the temptation to cheat to get the coveted admissions or scholarships must have been very powerful indeed. Udogi and Ivowi (1995) also identified inadequate preparation for the examination as a cause or factor that prompts examination malpractice. Watitwa (2010) on the other hand established that there is a statistically significant relationship between students' motivation and achievement in Biology practical work. Students who were motivated were more likely to achieve higher scores in Biology practical work. Myspacefm (2004), Newsberger (2003) and Udogi and Ivowi (1995) are all in agreement that poor study habits compromise the quality of education attained by students as most of them resort to cheating in examinations in order to get the coveted admissions or scholarships. Udoh (2011), Onyechere (1996) and Watitwa (2010) on the other hand established that poor study habits can be corrected by exposing students to a continuous assessment procedure which would enable them develop self-confidence. Ensuring that the students remained motivated was also likely to result in higher scores.

Entry behavior of students was established by Nakhanu (2009) as a factor affecting syllabus coverage. She further observed that students who entered form one with low Kenya Certificate of Primary Education marks were found to be slow learners and thus delayed coverage of the syllabus. This view is in agreement with that of Hallahan and Kauffman (1982) who observed that the child with learning disabilities needs individual tutoring in one or more areas of disability. Whether or not there is a resource teacher available would determine to a great extent how much of this instruction would be assumed by the regular class teacher. Low entry behavior was identified as a challenge experienced by headteachers in their attempt to provide quality education (Mobegi, 2007).In contrast Mwebi (2012) established that the high quality of students admitted in private universities in Kenya and the high students' evaluation in various programs was a contributing factor in the expansion of private universities in Kenya. Nakhanu (2009), Mobegi (2007) and Hallahan and Kauffman (1982) agree that entry behavior can affect the quality of education provided for students. These findings further agree with those of Mwebi (2012) who established that high entry behavior leads to provision of quality education.

Peer influence was identified by Udogi and Ivowi(1995) as a factor that prompts examination malpractices. Peer tutoring, having one individual tutor another, was established by Hallahan and Kauffman(1982) as an example of compensatory programs that focus on the teaching of basic skills but allow for changes in procedures to compensate for the special needs of the individual. According to Burke and Sass (2008) the weakest students appear to experience the biggest positive impact from having higher quality peers.

They further established that the highest-ability students actually benefit significantly from mixing with students of middle ability. While low ability students appear to benefit significantly from having top-quality peers, those peers will experience reductions in achievement gains from mixing with students of very low ability, reductions that may fully affect the weaker students' gains. The studies mentioned established that peer influence can be negative as researched by Udogi 


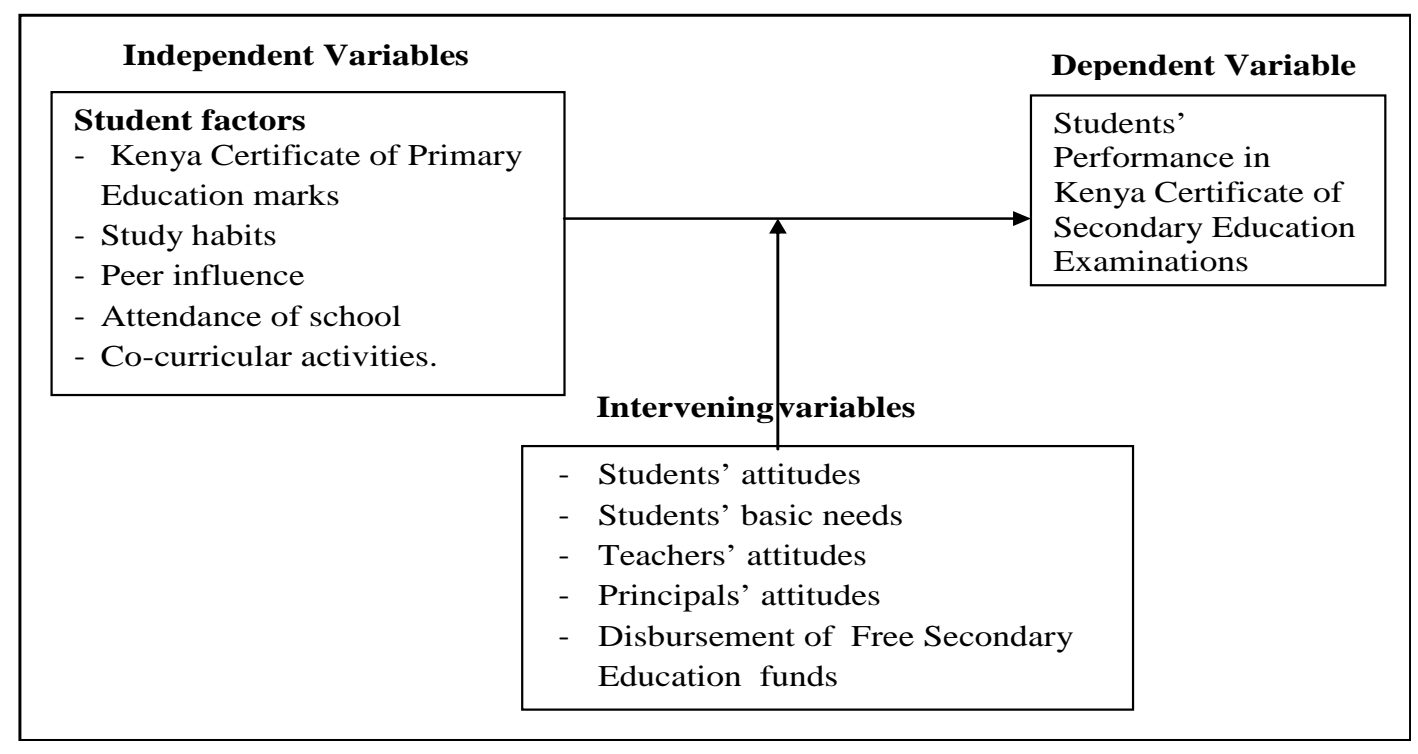

Figure 1: Student Factors influencing Academic Performance of students in Secondary Education

and Ivowi (1995) as well as positive, as established by Burke and Sass(2008).

Absenteeism of students was established by Nakhanu (2009) as a factor that affects syllabus coverage. According to Mobegi (2007) student absenteeism contributed to low performance. These findings agree with those of Odumbe (2012) who established that absenteeism of students and low family income had a negative influence on performance as the latter affected regular pupil attendance in school influencing the payment of fees. Long absence from school due to various reasons was found to be a factor that prompted school authorities' decision to force some students to repeat a given grade (Bucheche, 2011). The studies by Nakhanu (2000), Mobegi (2007), Odumbe (2012) and Bucheche (2011) all established that student absenteeism contributed to low performance as it affected syllabus coverage and sometimes led to some students repeating a given grade.

Student indiscipline was identified as a challenge experienced by head teachers in their attempt to provide quality education. Head teachers also reported that indiscipline cases contributed to low performance (Mobegi, 2007). Indiscipline was further identified by Bucheche (2011) as a factor leading to repetition caused by persistent poor academic performance.

\section{Conceptual Framework}

The following conceptual framework envisions the selected factors that interplay to influence provision of quality secondary education (Figure 1).

The conceptual framework postulated that various students factors can influence students' performance in secondary education. Students' low Kenya Certificate of Primary Education marks, poor study habits and indiscipline may result in low mean grades at Kenya Certificate of Secondary Education. Conversely good study habits, discipline and high Kenya Certificate of Primary Education marks may result in high mean grades at Kenya Certificate of Secondary Education.

However, the low mean grades can be avoided if students adopted a positive attitude and had their basic needs met and their school fees paid promptly by their parents. Similarly the teachers' factors that may positively influence the provision of quality education such as proper qualification and long teaching experience may not produce the expected results if the teachers' attitudes are negative. All independent variables therefore can influence students' academic performance in secondary education either negatively or positively depending on their nature and also considering the impact of the intervening variables upon them.

\section{RESEARCH METHODOLOGY}

The study employed ex-post-facto and correlational research designs. The study population consisted of 324 principals, 324 deputy principals, 9,000 candidates and the County Quality Assurance and Standards Officer. The study sample will consist of 176 principals, 176 deputy principals, 1760 candidates selected through multi stage 
076 Educ. Res.

Table 1: Principals' Demographic Characteristics

\begin{tabular}{lcc}
\hline Demographic Characteristic & Frequency (f) & Performance (\%) \\
\hline Gender & & \\
Male & 116 & 65.9 \\
Female & 60 & 34.1 \\
Total & $\mathbf{1 7 6}$ & $\mathbf{1 0 0}$ \\
Qualification & & \\
B.SC & 2 & 1.1 \\
B.ED & 148 & 84.1 \\
MA & 3 & 1.7 \\
M.ED & 23 & 13.1 \\
Total & $\mathbf{1 7 6}$ & $\mathbf{1 0 0}$ \\
Age (in years) & & \\
$36-45$ & 26 & 14.8 \\
$46-55$ & 124 & 70.4 \\
$56-60$ & 26 & 14.8 \\
Total & $\mathbf{1 7 6}$ & $\mathbf{1 0 0}$ \\
\hline
\end{tabular}

Table 2: Principals' Headship Experience and Teaching loads

\begin{tabular}{lcc}
\hline Demographic Characteristic & Frequency $(\mathbf{f})$ & Percentage \\
\hline Experience in current station & & \\
1-5 years & 43 & 27.8 \\
6-10 years & 113 & 64.3 \\
11-12 years & 14 & 7.9 \\
Total & $\mathbf{1 7 6}$ & 100 \\
Experience in other stations & & \\
0-1 years & 117 & 65.4 \\
2-5 years & 45 & 26.6 \\
6-8 years & 14 & 8.0 \\
Total & $\mathbf{1 7 6}$ & $\mathbf{1 0 0}$ \\
Teaching load (lessons) per week & & \\
3-9 & 100 & 56.8 \\
10 -15 & 76 & 43.2 \\
Total & $\mathbf{1 7 6}$ & $\mathbf{1 0 0}$ \\
\hline
\end{tabular}

and proportionate sampling techniques and 1 County Quality Assurance and Standards Officer selected through the saturated sampling technique. Data was collected by use of questionnaires, interview schedules, focus group discussion and document analysis guide. Validity of the instruments was determined by experts in educational administration. Reliability of the instruments was determined through a pilot study in $32(9.8 \%)$ schools whereby Pearson's $r$ was performed to establish the coefficient of reliability at the set $p$-value of 0.05 . The principals' questionnaire had a pearson's "r" coefficient of .8 which meant the questionnaire was reliable. Quantitative data was analyzed using descriptive statistics in form of frequency counts and percentages. Inferential statistics, that is, regression analysis, was used to establish the influence. Qualitative data was organized into themes and sub-themes as according to objectives.

\section{RESULTS}

\section{Demographic Characteristics of Principals}

The respondents of this study included school principals, Kenya Certificate of Secondary Education candidates (2011 Cohort) and the County Quality Assurance and Standards Officer. The demographic characteristics of the principals were as shown in Tables 1 and 2 .

Table 1 provides demographic characteristics of 
principals. It can be observed that out of the 176 principals involved in the study $116(65.9 \%)$ were male whereas $60(34.1 \%)$ were female. This shows that very few female teachers are appointed as school principals in Kakamega County. This is in agreement with a study carried out in a sampled number of schools in Kenya by Bosire et al (2009) who indicated that out of the sampled school principals $22(79 \%)$ were male while $6(21 \%)$ were female. From Table 1 it can further be observed that $2(1.1 \%)$ of the principals are holders of a BSC degree; $148(84.1 \%)$ have a B.ED degree; $3(1.7 \%)$ are holders of the MA degree and 23(13.1\%) are holders of an MA degree Age in years of the principals. Twenty six (14.8\%) were aged between 36-45 years; $124(70.5 \%)$ were aged between 46-55 years and 26(14.8\%) were aged between $56-60$ years.

The demographic data was further used to establish headship experience in their current stations and in previous stations as well as their teaching loads. The results are as shown in Table 2 above.

From the findings in Table 2, it can be observed that only $14(7.9 \%)$ of the principals had served as principals for over 10 years, whereas 49(27.9\%) had served for between $1-5$ years. 113(64.1\%) had served for 6-10 years. Table 2 further shows the headship experience of the principals in other stations. One hundred and seventeen (66.5\%) principals were serving as principals for the first time in their current stations. Forty five (25.6\%) had previously served as principals for a period of 2-5 years and $14(8 \%)$ had served for between 6-8 years previously workload of the principals. One hundred (56.8\%) taught between 0-9 lessons in a week whereas 76(43.2\%) taught between 10-15 lessons per week.

School data with regard to number of students per school, number of form four students, number of streams per school, average class size, frequency of testing policy, teacher-student ratios and book-student ratios were tabulated and are shown in Table 3.

It can be observed from Table 3 that most of the schools had a population of 200 students and below as shown by a frequency of $71(40.3 \%)$. This means that most of the schools were starting schools which are mainly characterized by low enrolment, shortage of teachers and shortage of other facilities such as textbooks, libraries and laboratories. Only $7(4.0 \%)$ of the schools had a population of 1000 students and above. It can be observed that $103(60.6 \%)$ of the schools were single-streamed. Most schools had a candidature of 1240(34.7\%) and 41-. 80(34.1\%). Average class size which shows that $107(60.8 \%)$ of the schools had an average class size of $18-45$ whereas $66(37.5 \%)$ had an average class size of $50-60$. Ninety nine $(56.3 \%)$ of the schools had a teacher-student ratio of between 1:9 and 1:15, sixty four (36.3\%) had a teacher-student ratio of between 1:16 and 1:20, thirteen (7.4\%) had teacher-student ratio 1:21 and above. Eight (4.5\%) of the schools had achieved a book student ratio of $1: 1$ and $31(17.6 \%)$ of the schools had a book-student ratio of 1:2.

\section{Research Objective}

The research objective was to: Establish the influence of student factors on students' academic performance in secondary education in Kakamega County.

The study sought to establish the influence of various student factors on the performance of students in the Kenya Certificate of Secondary Education examination. These factors were: school unrest, (for 2011 the cohort), average age (for the 2011 cohort), absenteeism from school, class and prep, exclusion from school and participation in co- curricular activities.

The data for the student factors was obtained from the responses of the principals in the questionnaires and it is tabulated in Table 4.

Further, from the responses in the Principal's questionnaires the dependant variable (2014 Kenya Certificate of Secondary Education performance) was also established and was as shown in Table 5.

To establish the influence of the student factors on students performance in Kenya Certificate of Secondary Education, statistical analyses in the form of Pearson product moment correlation and regression analysis were carried out. Correlation analysis between the student factors and Kenya Certificate of Secondary Education performance was computed and the results are as shown in Table 6.

From Table 6 it can be observed that there was a strong positive relationship between the Kenya Certificate of Secondary Education. The relationship was significant $(\mathrm{r}=.846, \mathrm{~N}=176, \mathrm{P}<.05)$. This means that increase in Kenya Certificate of Primary Education performance improves performance in Kenya Certificate of Secondary Education. Interview findings indicated that good performance guarantees good performance at Kenya Certificate of Secondary Education. Data from document analysis showed that some students who entered form one with relatively low Kenya Certificate of Primary Education marks went on to perform well in Kenya Certificate of Secondary Education. The questionnaire findings further established that there was a moderate negative relationship $(P<.05)$ between a candidate's age and their performance in Kenya Certificate of Secondary Education $(r=-520, N=176, P<.05)$. This means that an increase in age beyond 18 years reduces students' performance in Kenya Certificate of Secondary Education. An older candidate would therefore negatively influence students academic performance in Kenya Certificate of Secondary Education. In the interview with the deputy principals one of them described the 
078 Educ. Res.

Table 3: School Data

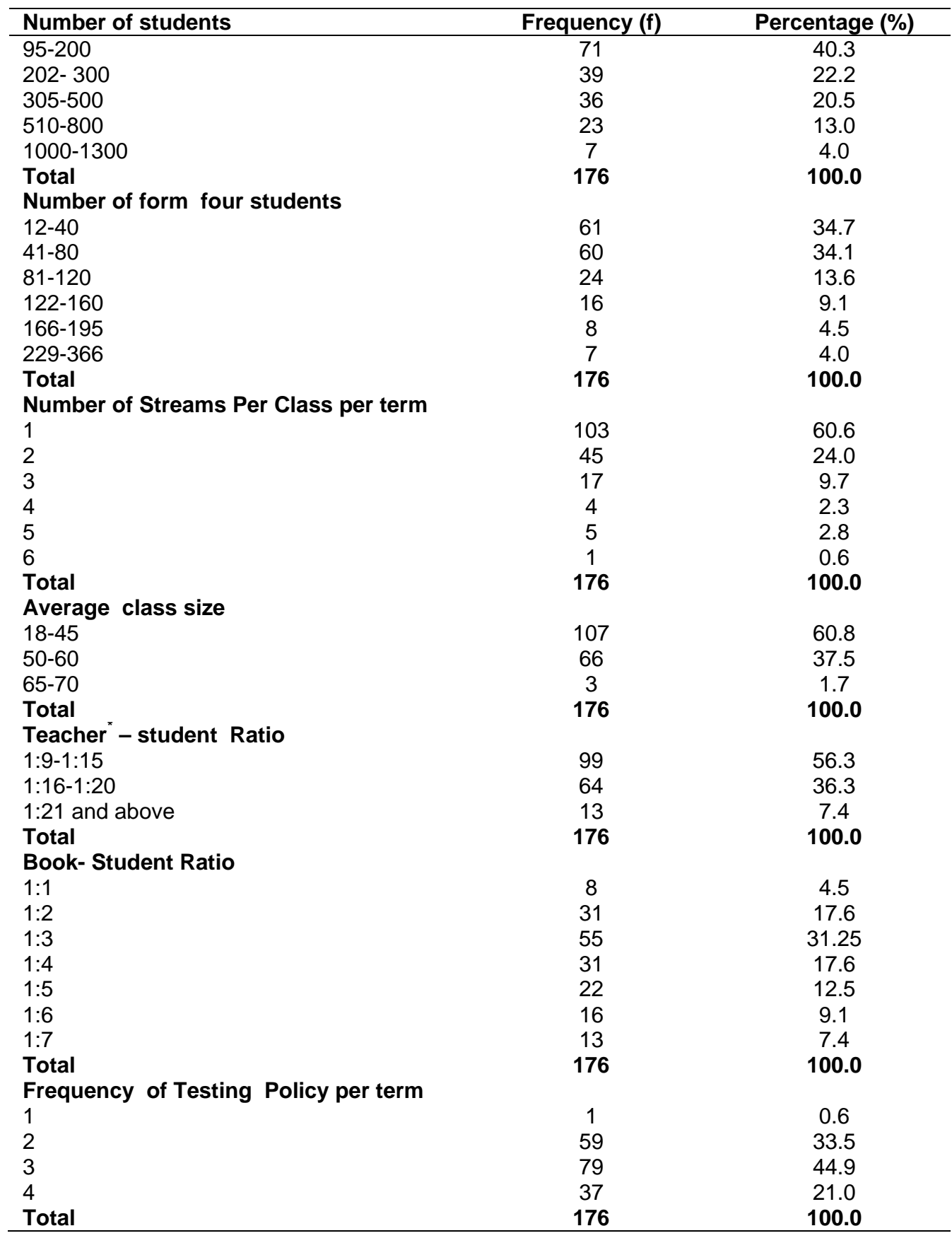

*Teachers included: Teachers Employed by Teachers Service Commission and Boards of Management of secondary schools

students aged above 18 years as slow learners who joined secondary school with low Kenya Certificate of Primary Education marks. He observed that most of them were over 18 because they repeated classes either at primary level and/or at secondary level. In yet another interview a deputy principal described the students aged above 18 years as: "having discipline problems and more likely to flout rules they also had problems with taking instructions from their younger peers making it difficult for them to benefit from group 
Table 4: Student Factors as Indicated by Principals in the Questionnaires $(n=176)$

\begin{tabular}{|c|c|c|}
\hline Student factor & Frequency ( $f$ ) & Percentage (\%) \\
\hline \multicolumn{3}{|l|}{ School Unrest (2011) } \\
\hline Nil & 164 & $93.2 \%$ \\
\hline 1 & 12 & 6.8 \\
\hline Total & 176 & 100 \\
\hline \multicolumn{3}{|l|}{ School Unrest (2012) } \\
\hline Nil & 126 & 71.6 \\
\hline 1 & 50 & 28.4 \\
\hline Total & 176 & 100 \\
\hline \multicolumn{3}{|l|}{ School Unrest (2013) } \\
\hline Nil & 155 & 88.1 \\
\hline 1 & 21 & 11.9 \\
\hline Total & 176 & 100 \\
\hline \multicolumn{3}{|l|}{ School Unrest (2014) } \\
\hline Nil & 172 & 97.7 \\
\hline 1 & 4 & 2.3 \\
\hline Total & 176 & 100 \\
\hline Average Kenya Certificate of Primary Education Mark & & \\
\hline $180-249$ & 72 & 40.9 \\
\hline 250-349 & 65 & 36.9 \\
\hline $350-399$ & 38 & 21.6 \\
\hline $400-450$ & 1 & 0.6 \\
\hline Total & 176 & 100 \\
\hline \multicolumn{3}{|l|}{ Cases of Exclusion (2011) } \\
\hline Nil & 155 & 88.1 \\
\hline 1 & 16 & 9.1 \\
\hline 2 & 5 & 2.8 \\
\hline Total & 176 & 100 \\
\hline \multicolumn{3}{|l|}{ Cases of Exclusion (2012) } \\
\hline Nil & 53 & 30.1 \\
\hline 1 & 84 & 47.7 \\
\hline 2 & 38 & 21.6 \\
\hline 3 & 1 & 0.6 \\
\hline Total & 176 & 100 \\
\hline \multicolumn{3}{|l|}{ Cases of Exclusion (2013) } \\
\hline Nil & 131 & 74.4 \\
\hline 1 & 35 & 19.9 \\
\hline 2 & 10 & 5.7 \\
\hline Total & 176 & 100 \\
\hline \multicolumn{3}{|l|}{ Cases of Exclusion (2014) } \\
\hline Nil & 174 & 98.9 \\
\hline 1 & 1 & 0.6 \\
\hline 2 & 1 & 0.6 \\
\hline Total & 176 & 100 \\
\hline \multicolumn{3}{|c|}{ Participation in co-curricular Activities (Number of times in a week) } \\
\hline Nil & 2 & 1.1 \\
\hline 1 & 52 & 29.5 \\
\hline 2 & 59 & 33.5 \\
\hline 3 & 29 & 16.5 \\
\hline 4 & 12 & 6.8 \\
\hline 5 & 21 & 11.9 \\
\hline 6 & 1 & 0.6 \\
\hline Total & 176 & 100 \\
\hline \multicolumn{3}{|l|}{ Average age } \\
\hline 17 years & 6 & 3.4 \\
\hline 18 years & 102 & 58.0 \\
\hline 19 years & 68 & 38.6 \\
\hline Total & 176 & 100 \\
\hline Absenteeism (2011- 2014) & Total (no of times) & Average \\
\hline From school & 11786 & 52.90 \\
\hline From class & 8255 & 37.00 \\
\hline From prep & 2241 & 10.10 \\
\hline Total & 22282 & \\
\hline
\end{tabular}

activity which otherwise boost their academic performance"
Regression analysis was performed to estimate the influence of the student factors on Kenya Certificate of 
080 Educ. Res.

Table 5: 2014 Kenya Certificate of Secondary Education Performance for the Selected Schools. $(n=176)$

\begin{tabular}{lll}
\hline K.C.S.E Performance & Frequency $(\mathbf{f})$ & Percentage (\%) \\
\hline $2.70-4.99$ & 90 & 51.1 \\
$5.00-5.99$ & 37 & 21.0 \\
$6.00-6.99$ & 19 & 10.8 \\
$7.00-7.99$ & 16 & 9.1 \\
$8.00-8.99$ & 10 & 5.7 \\
$9.00-9.99$ & 3 & 1.7 \\
$10.00-10.99$ & 1 & 0.6 \\
Total & $\mathbf{1 7 6}$ & $\mathbf{1 0 0}$ \\
\hline
\end{tabular}

Table 6: Pearson's Product Moment Correlation between Student Factors and Performance in Kenya Certificate of Secondary Education $(n=176)$

\begin{tabular}{lcc}
\hline Independent Variable (Student Factors) & & $\begin{array}{c}\text { Dependent Variable (Kenya Certificate } \\
\text { of Secondary Education performance) }\end{array}$ \\
\hline School unrest & $\mathrm{r}$ & .090 \\
Kenya Certificate of Primary Education Mark & $\mathrm{p}$ & .232 \\
& $\mathrm{r}$ & 176 \\
Average age & $\mathrm{p}$ & .846 \\
& $\mathrm{~N}$ & .000 \\
Absenteeism from school & $\mathrm{p}$ & 176 \\
& $\mathrm{p}$ & -.502 \\
Absenteeism from class & $\mathrm{N}$ & .000 \\
& $\mathrm{p}$ & 176 \\
Absenteeism from prep & $\mathrm{N}$ & .065 \\
& $\mathrm{r}$ & .393 \\
& $\mathrm{p}$ & 176 \\
Exclusion from school & $\mathrm{N}$ & .044 \\
& $\mathrm{r}$ & .565 \\
Participation in co-curricular Activities & $\mathrm{p}$ & 176 \\
& $\mathrm{~N}$ & .290 \\
& $\mathrm{r}$ & .000 \\
& $\mathrm{p}$ & 176 \\
& $\mathrm{~N}$ & 0.72 \\
& $\mathrm{r}$ & .345 \\
& $\mathrm{p}$ & 176 \\
& $\mathrm{~N}$ & .753 \\
& $\mathrm{y}$ & .000 \\
& & 176 \\
\hline
\end{tabular}

$\mathbf{r}$ - Pearson correlation coefficient $\mathbf{p}$ - Significance level $\mathbf{N}-$ Number of cases /participants

Secondary Education performance. The regression model consisted of eight independent variables; school unrest, Kenya Certificate of Primary Education mark, average age, absenteeism from school, class and prep, exclusion from school and participation in co-curricular activities. Table 7 shows the regression model summary of student factors and performance in Kenya Certificate of Secondary Education.

As shown in Table 7 the correlation between student factors (participation in co-curricular activities, exclusion from school, absenteeism from school, class and prep, school unrest, average age and Kenya Certificate of Primary Education mark) and Kenya Certificate of Secondary Education performance yielded an adjusted $R$ square $\left(R^{2}\right)$ of 0.756 . This implied that $75.6 \%$ of the total variance in Kenya Certificate of Secondary Education performance was accounted for by the student factors (participation in co-curricular activities, exclusion from school, school unrest, average age and Kenya Certificate of Primary Education mark) 
Waseka and Simatwa, 081

Table 7: Regression Analysis of Student Factors and KCSE Performance.

\begin{tabular}{lllll}
\hline Model & $\mathbf{R}$ & $\mathbf{R}$ square & Adjusted R square & Std. Error of the estimate \\
1 & $.876^{\mathrm{a}}$ & .768 & .756 & .835 \\
\hline
\end{tabular}

a. Predictors (constant), co-curricular, exclusion, absenteeism from class, school unrest, average age of 18 years, Kenya Certificate of Primary Education mark, absenteeism from prep, absenteeism from school.

Table 8: ANOVA for the Relationship between Student Factors and Kenya Certificate of Secondary Education Performance

\begin{tabular}{llccccc}
\hline & Model & Sum of Squares & Df & Mean square & F & Sig. \\
\hline \multirow{2}{*}{1} & Regression & 384.622 & 8 & 48.078 & 69.955 & $.000^{\mathrm{b}}$ \\
& Residual & 116.437 & 167 & .697 & & \\
& Total & 501.059 & 175 & & & \\
\hline
\end{tabular}

a. Dependant Variable : 2014 mean score

b. Predictors (constant), co-curricular, exclusion, absenteeism (class, school, prep) unrest, average age, Kenya Certificate of Primary Education mark

Table 9: Multiple Regression Analysis the Influence of Student Factors on Kenya Certificate of Secondary Education Performance

\begin{tabular}{|c|c|c|c|c|c|}
\hline Model & Unstandardized & coefficients & Standardized coefficients & $\mathbf{t}$ & Sig \\
\hline & $\mathbf{B}$ & Std . Error & Beta & & \\
\hline (constant) & 5.700 & 2.633 & & 2.165 & .032 \\
\hline School Únrest & -0.078 & 0.091 & -0.034 & -0.859 & .392 \\
\hline Kenya Certificate of Primary & 0.18 & 0.002 & 0.649 & 9.569 & .000 \\
\hline \multicolumn{6}{|l|}{ Education Mark } \\
\hline Age (18 years) & -0.339 & 0.137 & 0.110 & -2.479 & .014 \\
\hline Absenteeism from School & 0.004 & 0.002 & 0.496 & 1.721 & .087 \\
\hline Absenteeism from Class & -0.003 & 0.002 & -0411 & -1.331 & .185 \\
\hline Absenteeism from Preps & $-7.231 E-005$ & 0.005 & 0.002 & -0.015 & .988 \\
\hline Exclusion from school & 0.142 & 0.066 & 0.091 & 2.161 & .032 \\
\hline Co-curricular activities & 0.096 & 0.032 & 0.194 & 3.021 & 0.003 \\
\hline
\end{tabular}

a. Dependant Variable: 2014 Academic performance

and other factors constituting $24.4 \%$ apart from these student factors equally contributed to the performance in Kenya Certificate of Secondary Education.

From Table 8 it can it can observed that student factors were significant predictors of Kenya Certificate of Secondary Education performance ( $F$ $(8,167=69 ., P<.05)$.

Table 9 shows that out of the eight variables four were statistically significant at 0.05 levels. The variables of Kenya Certificate of Primary Education mark was significant $(P=0.00)$, indicating that Kenya Certificate $f$ Primary Education mark was a significant predictor of Kenya Certificate of Secondary Education performance. This means that an increase in one unit of Kenya Certificate of Primary Education mark will increase performance in Kenya Certificate of Secondary Education by 0.18 units as signified by a coefficient of 0.18 . Age as a significant factor influencing provision of quality secondary education as the calculated $p$-value of 0.014 was less than the set $p$-value of 0.05 . The influence of age on Kenya Certificate of Secondary Education performance was however negative. This means that an increase in one unit of the age of a candidate will decrease performance in Kenya Certificate of Secondary Education by 0.339 units as signified by a coefficient of -0.339. Exclusion from school $(P=.032)$ was a significant predictor of Kenya Certificate of Secondary Education performance as the calculated $p$ - value of 0.032 was less than the set $p$-value of 0.05 . Participation in cocurricular activities positively influenced performance in Kenya Certificate of Secondary Education. The variable of participation in that an increase in one unit of 
participation in co-curricular activities was significant as the calculated $p$-value of 0.003 was less than the set $\mathrm{p}$ - value of 0.05 . This means that an increase in one unit of participation in co- curricular activities will increase performance in Kenya Certificate of Secondary Education by 0.096 units as signified by a coefficient of 0.096 . It can therefore be deduced that reduced participation in cocurricular activities negatively affected results obtained in Kenya Certificate of Secondary Education .

\section{DISCUSSION}

All the principals had the required level of education. To understand and give the relevant information regarding the influence of selected factors on students' academic performance in secondary education. The fact that most of the principals were aged between $46-55$ years is an indication that they had served for many years in the teaching profession and therefore had a good grasp of the factors influencing students' academic performance in secondary education. Most of the principals had been in their current stations for a considerable period of time and were therefore well versed with the factors influencing students' academic performance in their schools. Most of the principals who were serving as principals for the first time in their current stations had considerable experience as principals to be able to fully comprehend and assess the influence of various factors on students' academic performance in secondary education. Principals had good curriculum leadership and could therefore be relied upon to give information related to the influence of various factors on students' academic performance in secondary education. Most of the schools were starting schools which were still having challenges with staffing and provision of essential facilities such as staff houses and boarding facilities for students. Single stream class were day schools where students faced numerous challenges such as walking long distances to school, lack of sufficient teacher-student contact hours and lack of reading opportunities at night. This was likely to have a negative influence upon students' academic performance in secondary education in Kakamega County.

From the interviews with the deputy principals and analysis of available documents such as class registers and enrolment trends it emerged that there were schools which were registered as double-stream schools but on the ground only had one stream. This was attributed to emergence of numerous new schools in the same neighborhood which caused mass movement of students most of whom were unable to pay school levies and therefore moved to a neighboring school to avoid dropping out of school altogether. From the analysis of available documents it emerged that the lower ratios were ironically in the schools with low population of students. This was because the Board of Management employed teachers were unqualified form IV graduates. The low enrolment translated to insufficient funds to purchase teaching and learning materials, hire qualified teachers and avail facilities such as libraries, laboratories and staff houses which are essential in facilitating provision of quality secondary education.

A deputy principal described students who entered form one with high Kenya Certificate of primary Education marks as "motivated, easier to learn and that they also easily grasped the various concepts in class causing them to score high grades in class and eventually in Kenya Certificate of Secondary Education ". Those with low entry marks on other hand were said to lack self confidence, had low self-esteem and performed below average in class and eventually in Kenya Certificate of Secondary Education. In the interview with the County Quality Assurance and Standards Officer, his views were in agreement with the questionnaire findings. He observed that national and county schools required a higher entry mark on admission and usually performed better in Kenya Certificate of Secondary Education as compared to sub county schools which admitted students with lower marks at Kenya Certificate of Primary Education. From the Focus Group Discussion it emerged that the candidates themselves had similar views as established through the questionnaire findings. They observed that their peers who performed well at Kenya Certificate of Primary Education level went on to perform well in secondary school. When asked about some of their peers who had not performed well in Kenya Certificate of Secondary Education one observed; " that one (referring to a classmate who had scored a $\mathrm{D}+$ ) a previous cohort even in primary school was always behind, in fact she repeated class six and seven." These findings are in agreement with those of Nakhanu (2009) who established entry behaviour of students as a factor affecting syllabus coverage. She observed that students who entered form one with low Kenya Certificate of Primary Education marks were found to be slow learners and thus delays coverage of the syllabus. Mobegi (2007) similarly identified low entry behaviour as a challenge experienced by head teachers in their attempt to provide quality education. In some of the schools they had even performed better that their peers who scored higher marks than them at Kenya Certificate of Primary Education. This could be attributed to various factors. Some of the students who had been in day schools at Kenya Certificate of Primary Education seem to have faced insurmountable challenges causing them to perform poorly. However with the advantage of boarding school at secondary level they went on to perform well in Kenya Certificate of Secondary Education. This exception to the rule could also be 
attributed to students who were in Primary schools that were understaffed and with limited facilities such as text books. Going to secondary school that had adequate facilities would enable them score high marks at Kenya Certificate of Secondary Education because these factors are controlled at Secondary school however, and a student may eventually score high grades at Kenya Certificate of Secondary Education.

From the Focus Group Discussion the candidates described their counterparts aged above 18 years as bossy and not open to criticism and correction. One candidate described one such classmate as: "suffering from low self esteem and always on the defensive even when the views he holds are not correct. He will not accept correction thus making it difficult for them to get along with other." These traits made it difficult for these students, most of whom were low achievers to benefit from teachers and their peers, which would have greatly improved their grades. These sentiments are consistent with the findings of Burke and Sass (2008) who established that weak students appear to experience the biggest positive impact from having top quality peers. The findings of this study further agree with those of Bucheche (2011) who established that persistent poor academic performance was a factor that led to repetition causing students to be overage for a particular class. Similarly, studies by Nakhanu (2009), Mobegi (2007) and Odumbe (2012) established that low performance in school led to some students repeating a given grade thus causing them to lag behind their peers due to their advanced age. An analysis of available documents brought to light other reasons for candidates being overage. For instance there were girls who had dropped out of school due to teenage pregnancies and decided to go back to school. There were also boys who dropped out due to lack of fees or child labour and later decided to resume school. This study established that even though these students were not overage due to having a low aptitude they still performed comparatively lower due to being out of sync with their peers. They tended to be domineering or lacking in self esteem thus unable to utilize fully the cooperation and knowledge of their classmates.

It was further established through the questionnaire findings that there was a strong positive and significant relationship between student participation in co-curricular activities and performance in Kenya Certificate of Secondary Education $(r=.753, N=.176, P=.05)$. This means that increase in student participation in cocurricular activities improves their performance in Kenya Certificate of Secondary Education. A student who participated regularly in co-curricular activities was therefore likely to perform better in Kenya Certificate of Secondary Education than his counterpart who seldom participated or engaged in co-curricular activities. In the interview with the County Quality Assurance and Standards Officer acknowledged that most of the schools that performed well in academics in the County had an established culture of student participation in sports and co-curricular activities. He also added that schools that did not put emphasis on participation in sports and cocurricular activities failed to achieve optimum results in academics from their students especially in the Kenya Certificate of Secondary Education examination. From the interviews with the deputy principals it was evident that they were in agreement with the findings from the questionnaires. One deputy principal described students who participated in co-curricular activities as "focused, attentive in class and good time managers" which caused them to easily excel in academics.

In a different school that had an established routine and culture of participation in co-curricular activities the deputy principal described the students as "self motivated, having the ability to multi- task and participated actively in group activities". In contrast a deputy principal of a school where candidates seldom participated in sports and co-curricular activities, described the candidates as "inactive", irritable and lacking motivation and self drive." From these findings it was evident that candidates who frequently participated in sports and co-curricular activities had an advantage over their less active peers as they had better chances of performing better academically. Similarly from the Focus group discussion the candidates were in agreement with the findings from the interviews. They concurred that their more active peers who participated frequently in sports and co-curricular activities were more active in class and also performed well in academics. In a different school where students rarely engaged in sport and curricular activities but had a vigorous academic schedule nonetheless students told of feeling fatigued, exhausted and unable to concentrate during evening prep. One student said: "By evening I usually feel exhausted, fatigued and sleepy and yet there is so much to do which makes me feel like everything is too much" This unlike a student from a school that had a deliberate program for candidates to engage in sports said "by afternoon we are usually exhausted because we wake up very early in the morning and our timetable is usually packed. However because sports is compulsory for candidates at 4.00 o'clock we usually feel refreshed and feel active enough to tackle the evening program."

In some of the schools however, document analysis provided exceptions to the above findings. Schools that had an established culture of excellence in a particular sport seemed to admit students specifically for the sport. These were the students who participated actively and excelled in co-curricular activities but nonetheless performed poorly in class and in examinations. Their 
Kenya Certificate of Primary education mark was also low thus establishing that participating in co-curricular activities alone does not guarantee excellence in academics. There are other factors to consider such as aptitude, parental guidance as well as academic foundation. Farooq et al. (2011) for example established that variables that affect students' quality of academic achievement are inside and outside of school. These could therefore be factors such as parental level of education, availability of study time, study habits or even the discipline of the students themselves. Mobegi (2007) and Bucheche (2011) both identified discipline as a factor that contributed to low academic performance. From the interview with some of the deputy principals they asserted that Orphaned and Vulnerable Children faced unique challenges that contributed to their low performance as did students who lived with terminally ill parents. Students in the Focus Group Discussion also told of challenges alcoholic parents and lack of basic necessities such as soap sanitary towels that minimized their concentration in class causing them to perform poorly.

Participation in co- curricular activities positively influenced performance in Kenya Certificate of Secondary Education. These findings are in agreement with those of Jaiyeoba and Atanda (2011) in a study on 'School Quality Factors and Secondary School Students' achievements in Mathematics in South- Western and North -Central Nigeria" who established that good physical and mental health of school students is essential if they are to fully participate in education services being offered and if they are to concentrate and learn while at school. They are further consistent with those of Dwyer et al (1996) in a study titled 'Physical Activity and Performance in Children' who showed that there is growing evidence that regular physical activity enhances learning and school achievement and that physical activity fuels the brain with oxygen which enhances connections between nerves and assists in memory. They further established that children who participate in daily activity have shown superior academic performance and better attitudes towards school. What this meant was that availability of sports facilities which facilitates regular physical activity is also germane to effective learning. These views are further weighted by Kataka (2011) in a study titled 'Management of Resources in Secondary Schools and its Implications on the level of Participation in Non -Formal Curricular Activities' who is established that participation in non- formal curricular activities has enormous benefits. Similarly, Mbola (2010) in a study titled 'Participation in Sports and Academic Performance of Secondary School Students in Rachuonyo District' demonstrated that sports play a crucial role in education including creating self esteem and confidence, ability to develop language which makes students understand and communicate ideas more effectively as well as being more regular in school due to good health. Further through sports students develop ability to work for long periods, their bodies become flexible as well as being stronger than those who did not participate in sports. Participation in sports was therefore shown to affect academic performance positively as it refreshes the minds of students after the vigorous academic work to prepare them for further academic work. It was also established as enabling students to concentrate in academics for long periods thus improving their academic performance. An analysis of available documents however brought to light different findings. There were records of students who excelled in sports and co-curricular activities but whose performance in class and eventually in Kenya Certificate of Secondary Education was below average. Some of these students had been admitted to their respective schools for the sole purpose of adding value to the sports in which they participated, their grades notwithstanding. It was evident that little was done to assist such students achieve better grades academically in as much as the initial agreement was based upon their contribution to enable the schools excel in co-curricular activities.

Findings from document analysis indicated that students were mainly excluded from school due to issued related to discipline for example drug and alcohol abuse, boy-girl relationships that culminated into teenage pregnancies and involvement in school strikes or unrests. Excluding such students from school may therefore mean that students are free of negative influence and can therefore have ample time to concentrate on academics and excel. These findings concur with those of Mobegi (2007) who highlighted headteachers as reporting that indiscipline cases contributed to low performance. In further agreement are the findings of the interview with the County Quality Assurance and Standards Officer who observed that schools that had cases of school unrest and other discipline - related issues often performed poorly in academics as reflected in their Kenya Certificate of Secondary Education results. He noted that even schools that had a long standing history of performing well in examinations often performed poorly in the years when unrests or major discipline issues were highlighted in those schools. Similarly in the interviews with the deputy principals most of them observed that an indisciplined student often affected negatively their own as well as others' academic performance. In the Focus group discussion the respondents were able to cite examples of their peers who were bright but whose grades dropped drastically due to involvement in indiscipline that often caused them to miss school and/or class. A different candidate who had discipline 
problems that occasioned him to be away from school was described by his peers as: "Disruptive, not keen on group activity and found little time to concentrate on his studies." The positive impact of excluding a student from school can be attributed to the minimized disruptions that such student(s) would cause to a class thus negatively affecting their performance. The exclusion of such students would therefore cause the rest to concentrate on their studies knowing the repercussions of being indiscipline. Eventually this would have a positive impact on their academic performance. Data from document analysis in some of the schools indicated that some students were excluded from schools due to poor academic performance. Excluding such students from a class would inevitably cause the mean of such a class to go up. However effort needs to be put in rehabilitating students instead of excluding them. Whether indiscipline or low- achiever excluding a student simply transfers a problem to a different school or even causing them to drop out of school altogether negating the very essence of providing quality education to all. The other factors that were not significant were school unrests, absenteeism from school, absenteeism from class and absenteeism from preps.

\section{CONCLUSION}

The study revealed that participation in co-curricular activities greatly enhanced students' performance in Kenya Certificate of Secondary Education. Further, performance in Kenya Certificate of Primary Education was a strong predictor of possible outcomes in Kenya Certificate of Secondary Education. Additionally, overage reduced students performance in Kenya Certificate of Secondary Education and conversely younger age enhanced performance in Kenya Certificate of Secondary Education.

\section{RECOMMENDATIONS}

School unrests should be eradicated in schools as they negatively influence students performance, though they were found statistically not significant predictors. Principals of secondary schools should put in place value added programmes to enhance students performance in Kenya Certificate of Secondary Education by ensuring that students who join form one with whichever Kenya Certificate of Primary Education marks make progress.

The overage students should be guided and counselled effectively so as to improve students' performance in Kenya Certificate of Secondary Education. Student absenteeism reduces their performance, though not significantly. Consequently proactive measures should be put in place to control absenteeism so as to enhance academic performance.

Co-curricular activities for students should be encouraged in schools as they enhance significantly students academic performance. Exclusion from schools should be manipulated diligently so as to have high impact on students performance in Kenya Certificate of Secondary Education

\section{REFERENCES}

Ackerman RH, Moller G, Katzenmyer M (1996). Every Teacher as a leader. San Francisco: Jossey-Bass

Ahawo HA (2010). Factors Influencing Students' Academic Performance in Public Mixed

Day Sec. Schools in Kisumu East District, Kenya. An unpublished M.E.D Thesis: Maseno Uni.

Alberta Education (2012). The Principal Quality Practice Guide line. Promoting Successful

School Leadership in Alberta. Retrieved from ;http://education.alberta. $\mathrm{ca} / \mathrm{admin} / \mathrm{resources}$.aspx on 20th July 2013 at $2.00 \mathrm{pm}$.

American School Counsellor Association (2008). Effectiveness of School Counseling. Retrieved from http://www.schoolcounselor.org.on 22 July 2013 at 2.00

Anger B (2004).The Role of Parents on Academic Performance of Students in Nigeria Schools. A Conference Manual on Examination Malpractice and Campus Cultism. Benue State Ministry of Education in conjunction with the Centre for Economic and Social Development, Makurdi, Fermo Prints, Gboko, 2004

Anyiin TJ (1998). Examination Malpractice in Benue state Schools: The Way Forward. Seminar paper by the Cultism Committee, Makurdi, 1998.

Barnes D (1985). Practical Curriculum Study. Routledge and Kegan Paul. London.

Bogler R (2015.The Influence of Leadership style on Teacher Job Satisfaction. Edu.I Manag. Admin. and Leadership J. July 1, 2015 43:541-560.

Bosire J, Sang AK, Kiumi JK, Mungai VC (2009). The Relationship Between Principals' Managerial Approaches and Student Discipline in Sec. Schools in Kenya. An Intl. Multi Disciplinary J. Ethiopia.

Branch GF, Hanushek EA, Rivkin SG (2013). Measuring the Impact of Effective Principals. Edu. Next 2013/VOL. 13(1). educationnext.org

Brooks M, Janes WL (2010). Middle School Principals: The Relations between Gender and years of Administrative Experience to School's Academic Growth Trends. National Forum of Edu. Administration and Supervision J. Vol. 27(4): 2010

Bruce J, Hersh R, Mckibbin M (1983). The Structure of School Improvement. Longman Inc. New York.

Bucheche, S.E. (2011) Factors contributing to Wastage in Day and Boarding Sec. Schools in Mt. Elgon District, Kenya. An unpublished M.E.D Thesis: Maseno Uni.

Burke AM, Sass RT (2008) Classroom Peer Effects and Student Achievement. Working Paper 18. June 2008. www.urban.org

Calvo RA, Markauskaite L, Trigwell K (2000). Factors Affecting Students' Experiences

Chevedza E ,Wadesango N, Kurebwa M (2012). Factors that militate against the Provision of quality education at grade seven level in Gokwe South Central cluster of Zimbabwe. Intl. J. Edu. Sci. 4(3): 223-229 (2012).

Clark D, Mortorell P, Rockoff J (2009). School Principals and School Performance. Working paper No. 38-Dec. 2009. Centre for Analysis of Longitudinal Data in Education Res. New York.

Coelli M, Green AD (2011). Leadership Effects: School Principals and Student Outcomes. An Intl. J. Res. Policy and Practice. Vol.10(5) 2011. 
Creswell JW (2009).Res. Design, Qualitative, Quantitative and Mixed Methods Approaches. California SAGE.

Cohen L, Manion L (1998). Res. Methods in Edu. London: Routeledge Limited.

Council for Education Policy, Res. and Improvement (2003). Florida Teachers and the Teaching Profession. Teaching Profession Committee. Jan, 2003. Retrieved online on 22 July 2013 at 10.00am.

Denham RA (2013). How much does donor influence in setting educational policy in poor countries lead to improved quality outcomes? www.hiidunia.com

Dhuey E, Smith J (2013). How School Principals Influence Student Learning. National Forum of Educational Administration and Supervision J. Vol. 10, No. 112013.

Dwyer T, Blizzard L, Dean K (1996). Physical activity and performance in children. Nutrition Review, 54.4: 527-531.

EFA (2005). Understanding Education Quality. Global Monitoring Report, 2005. Retrieved online on 22 July 2013 at 11.00 am

Everard KB, Morris G, Wilson I (2004).Effective School Management. London: Paul Chapman Publishing.

Farooq MS, Chaudhry AH, Shafiq M, Berhamu G (2011). Factors Affecting Students' Quality of Academic Performance: A case of secondary school level. J. of Quality and Technology Manag. Vol. 7(2), Dec 2.011: 01-14.

Fatai K (2005). Causes, implications and solutions to Examination Malpractices in Ilorin East Local Government Secondary Schools. An unpublished B.Ed. Project of Arts and Social Science, University of Ilorin, llorin.

Gall MD, Borg WR, Gall JP (2007). Educational Research: An Introduction. Boston. Pearson International.

Gay L (1996). Edu. Res: Competence for Analysis and Applications. New Jersey: Maryland Imprint of Prentice Hall.

Hallahan PD, Kauffman JM (1982) Exceptional Children: Intro. to Special Edu. Prentice -Hall, Inc., Englewood cliffs.

Hallinger P, Heck HR (1998).School Effectiveness and School Improvement. An International Journal of Research Policy and Practice.Vol. 9(2).

Henard F, Roseveare D (2012). Fostering Quality Teaching in Higher Education: Policies and Practices. Institutional Management in Higher Edu. www.cad.auckland.ac.za. Retrieved on 20 July 2013 at 9.00am

Inter-American Development Bank (2008). The Quality of Education in Argentina. An IDB Res. Project. Jan. 2008. Retrieved on 23 July 2013 at 2.00am.

Jaiyeoba OA, Atanda AI (2011). School Quality Factors and Secondary School Students' Achievement in Mathematics in South-Western and North-Central Nigeria. The African Symposium: An online J. the African Edu. Res. Network.93 Vol(2): I June, 2011.

Kadzamira E, Rose P (2012).Educational Policy Choice and Policy Practice in Malawi: Dilemmas and Disjunctures. IDS Working Paper 124. www.ids.ac.uk

Kamuri P (2013). Report Shows Teacher Absenteeism Hurting Classroom Learning. The Standard. Wednesday, July $17^{\text {th }}$.

Kataka MN (2011). Management of Resources in Secondary Schools and its Implications on the level of participation in non-formal curricular Activities. An unpublished M.ED Thesis: MMUST.

Kathuri JN, Pals (1993). Intro. Edu. Res. Njoro: Educational Media Centre, Egerton Uni.

Kithi GY (2011). Factors Influencing Utilization of Educational Resources in Public Primary Schools in Kilifi District, Kenya. An unpublished M.ED Thesis: Maseno Uni.

Kombo DK, Tromp DLA (2006). An Introduction of Proposal and Thesis Writing. Nairobi: Pauline Publications Africa.

Leedy PD, Ormrod JE (2005). Practical Res: Planning and Design. New Jersey: Pearson Merril Prentice Hall.

Leithwood K, Anderson S, Louis KS, Wahlstrom K (2004). How Leadership Influences student Learning .European J. Edu. Vol. 31, No.4 2004.

Maende BJ (2012). Influence of Professional Development on Teacher
Effectiveness in

Public Sec. Schools in Mumias District, Kenya. An unpublished M.ED Thesis: Maseno Uni.

Matheri EW (2015) Effects of Principals' Gender on Leadership Effectiveness in secondary Schools in Mtito Andei Division, Kibwezi Sub County, Kenya. An Unpublished M.E.D Research Project: South Eastern Kenya University.

Mayeku B (2009). Policy Guidelines and Challenges in Quality Assurance in Distance Learning Programmes in Kenyan Public Universities. An unpublished M.ED Thesis: Maseno University.

Mbola TO (2010). Participation in Sports and Academic Performance of Secondary School Students in Rachuonyo District, Kenya. An unpublished M.ED Thesis: Maseno University.

Mc Burney DH, White TL (2010). Res. Methods. Wadsworth Cengage learning. United states of America.

Mingat A, Ledoux B, Rakotomalata R (2010). Developing Post-Primary Education in sub-Saharan Africa. The World Bank. Washington, DC.

Ministry of Education Science and Technology (1987). The Heads Manual for Schools. Nairobi. Ministry of Edu. Sci. and Tech.

Ministry of Education Science and Technology and ICT- Kakamega County (2014). Kakamega County Education Task Force Report.

Mobegi FO (2007). Quality Assurance Challenges and Opportunities for Public Secondary School Headteachers in Gucha District, Kenya. An Unpublished M.ED Thesis: Maseno University

Mugenda ON, Mugenda AG (2003). Res. Methods: Qualitative and Quantitative Approaches, Nairobi, Kenya: Acts Press.

Musungu LL (2007). Role of the Headteacher in Academic Achievement in Secondary Schools in Vihiga District, Kenya. An Unpublished M.ED Thesis: MasenoUni.

Mwebi B (2012). Expansion of Private Universities in Kenya and its Implication on Student Characteristics, Access Factors, Quality and Completion Rate. An unpublished PHD Thesis: Maseno University.

Myres BM (1997). Perceptions of Relationship between School-based Management, Programme Quality and Student Achievement. An unpublished PHD Thesis: Uni. of Alberta.

Myspacefm.com (2004). Interview with WAEC Officials conducted by Space FM $87.7 \mathrm{mhz}$. Retrieved online on $25^{\text {th }}$ November 2012 at 10.00am

Nakhanu SB (2009). Effect of syllabus Coverage on student Performance in Mathematics: A case of Kakamega South District. An unpublished MSC Thesis: MMUST

National Association of Secondary School Principals (2013).Importance of Principal Leadership. Retrieved from www.nassp.org.

Newsberger EH (2003). Why do students Cheat? Retrieved online on $25^{\text {th }}$ November 2012at 10.00am.

Nsubuga EHK (2000). Fundamentals of Educational Res..Kampala.MK Publishers (U) Ltd.

Nyabuto KB (2007). Grade Repetition in Kenyan Primary Schools. Issues of Learning Disabilities. Transaction Publishers. London. UK.

Odumbe GA (2012). Factors Influencing Student Academic Performance in Day Secondary Schools in Migori District, Kenya. An unpublished M.ED Thesis Maseno Uni.

Ogalo EA (2013). Influence of Principals' Leadership Styles on Students' Achievement in Kenya Certificate of Secondary Education in Awendo District, Kenya.http://erepository.uonbi.ac.ke

Okoth B (2010). The Impact of Principals' Leadership Styles on Performance in Public Sec. Schools in Kakamega Central District, Kenya. An Unpublished MSC Thesis: MMUST.

Omariba JN (2003). Factors that Contribute to Performance in Public Examinations in Rural Sec. Schools in Kisii District, Kenya. An unpublished M.ED Thesis: Maseno Uni.

Ong'ele AS (2007). Effects of Teacher Characteristics on Teaching of Mathematics in Secondary Schools in Kisumu District. An Unpublished M.ED Thesis Maseno Uni.

Oniye OA, Alawaye SA (2008). Female Students Perceived Causes of and Solution to Examination Malpractice in Asa Local Government: Implication for Counseling Sokoto Educational Review 10(2), June 2008.

Onyechere I (1996). Examination Ethics: Handbook. Yaba: NERDC 
Press.

Organization for Economic Co-operation and Development. (2013). School Factors Related to Quality and Equity.www.oecd.org

Orodho AJ (2004). Techniques of writing Res. Proposals and Reports in Edu. and Social Sci. Nairobi: Realta Printers.

Otieno LAO (2012). Stakeholders' Perceptions on Challenges faced by the Headteachers on the Provision of Quality Education in Public Secondary Schools in Nyando District, Kenya. An Unpublished M.ED Thesis: Maseno Uni.

Otunga R, Odero II, Barasa PL (2011). A Handbook for curriculum and Instruction. Eldoret: Moi Uni. Press.

Posner GJ (1992). Analyzing the Curriculum. McGraw-Hill. New York.

Punch KF (2005) Introduction to Social Research: Quantitative and Qualitative Approaches. London SAGE Publications Ltd.

Purkey S, Smith M (1983). Effective Schools: A review. Elementary School J., 83: $335-351$.

Republic of Kenya (2008). First Medium Term Plan, 2008-2012. Nairobi: Government Printer.

Republic of Kenya (2011). 2009 Census Report. Nairobi: Government Printer.

Rosner J (1985). Helping Children Overcome Learning Difficulties. Walker Publishing Company, Inc.USA.

Sammons P, Sylva K, Melhuish E, Blatchford IS, Grabbe Y, Taggaert B, Barreau S (2008). The influence of School and Teaching Quality in Children's Progress in Primary School. Institute of Education, Uni. of London. Res. Report No. DCSF -RR 028.

Sergiovanni JT, Starrat JR (2002). Supervision: A Redefinition. The McGraw-Hill Companies, Inc. New York.

Sichambo NM (2011). Impact of Burnout on Secondary School Teachers' Performance:

A case of Bungoma North District. An unpublished M.ED Thesis: MMUST.

Simatwa EMW (2007). Management of Student Discipline in Secondary Schools in Bungoma District, Kenya. An Unpublished PHD Thesis: Maseno Uni.

Tarus RS (2009).Impact of Headteachers' Leadership Styles on Sec. School Students' Academic Achievement in Nandi North District, Kenya. An unpublished M.ED Thesis: Maseno Uni.

The Basic Education Act (2013). Government Printer.

The Wallace Foundation (2012). How Leadership Influences Student Learning.www.wallacefoundation.org

The World Bank (2008). Textbooks and School library provision in Sec. Edu. in

Sub-saharan Africa. Washington.

Udogi A, Ivowi S (1995). Examination Malpractice: Profile causes, warning signs, case studies, prevention and detection strategies. Potomac Publications.
Udoh NA (2011). Remote causes and Counseling Implications of Examination Malpractice inNigeria. Student Pulse J.Vol.3.No.10, 2011.

Wakarindi KP (2013). Influence of Principals' Administrative Strategies on Students' Kenya Certificate of Secondary Education Performance in Mathioya District, Kenya. An Unpublished M.E.D Research Project: Uni. of Nairobi.

Wanja PM (2012). Factors Affecting Quality of Edu. in Public Day Secondary

Schools in Thika-Ruiru Division Thika District, Kenya.http://erepository. uonbi.ac.ke

Wanyonyi DK (2012). An investigation of factors affecting access to quality primary education by the physically challenged pupils in Kakamega and Bungoma Counties. An unpublished M.ED Thesis: MMUST

Wanyonyi R (2011). Influence of School Administration in promotion in effective guidance and counseling services in Secondary Schools in Bungoma West District. An unpublished M.ED. Thesis: MMUST

Wasilwa BJ (2012). Effects of Physical facilities on Kenya Certificate of Secondary Education performance in public secondary schools in Kenya: A case of Bungoma South District. An unpublished M.ED Thesis: MMUST.

Watitwa P (2010). An Investigation of Student Related Factors that Affect Achievement in Sec. Sch. Bio. Practicals in Teso District, Kenya. An unpublished MSC Thesis: MMUST. 